\title{
Comparison on batch anaerobic digestion of five different livestock manures and prediction of biochemical methane potential (BMP) using different statistical models
}

Gopi Krishna Kafle ${ }^{1, *}$, Lide chen ${ }^{2, * *}$

${ }^{1}$ Biological Systems Engineering, Washington State University, Pullman, WA 99164, USA

${ }^{2}$ Department of Biological and Agricultural Engineering, University of Idaho, Moscow, ID 83844, USA

* Corresponding author:-

Name: Gopi Krishna Kafle

Tel.: +1 509335 1578, fax: +1 5093352722

Email address: gopikafle@yahoo.com,gopikrishna.kafle@wsu.edu

** Corresponding author:-

Name: Lide Chen

Tel.: +1 208736 3615, fax: +1 2087360843

Email address: lchen@uidaho.edu

\footnotetext{
Abstract

(C) 2015. This manuscript version is made available under the Elsevier user license http://www.elsevier.com/open-access/userlicense/1.0/
} 
There is a lack of literature reporting the methane potential of several livestock manures under the same anaerobic digestion conditions (same inoculum, temperature, time, and size of the digester). And there is no literature reporting biochemical methane potential (BMP) predicting models developed and evaluated by solely using different livestock manure tests results. The goal of this study was to evaluate the BMPs of five different livestock manures (dairy manure (DM), horse manure (HM), goat manure (GM), chicken manure (CM) and swine manure (SM)) and to predict the BMPs using different statistical models. Nutrients of the digested different manures were also monitored. The BMP tests were conducted under mesophilic temperatures with a manure loading factor of $3.5 \mathrm{~g}$ volatile solids (VS)/L and a feed to inoculum ratio $(\mathrm{F} / \mathrm{I})$ of 0.5 . Single variable and multiple variable regression models were developed using manure total carbohydrate (TC), crude protein (CP), total fat (TF), lignin (LIG) and acid detergent fiber (ADF)), and measured BMP data. Three different kinetic models (first order kinetic model, modified Gompertz model and Chen and Hashimoto model) were evaluated for BMP predictions. The BMPs of DM, HM, GM, CM and SM were measured to be 204, 155, 159,259 , and $323 \mathrm{~mL} / \mathrm{g} \mathrm{VS}$, respectively and the VS removals were calculated to be 58.6, 52.9, $46.4,81.4,81.4 \%$, respectively. The technical digestion time ( $\mathrm{T}_{80-90,}$, time required to produce 80 $90 \%$ of total biogas production) for DM, HM, GM, CM and SM was calculated to be in the ranges of 19-28, 27-37, 31-44, 13-18, 12-17 days, respectively. The effluents from the HM showed the lowest nitrogen, phosphorus and potassium concentrations. The effluents from the CM digesters showed highest nitrogen and phosphorus concentrations and digested SM showed highest potassium concentration. Based on the results of the regression analysis, the model using the variable of LIG showed the best $\left(\mathrm{R}^{2}=0.851, \mathrm{p}=0.026\right)$ for BMP prediction among the single variable models, and the model including variables of $\mathrm{TC}$ and $\mathrm{TF}$ showed the best 
prediction for BMPs $\left(\mathrm{R}^{2}=0.913, \mathrm{p}=0.068-0.075\right)$ comparing with other two- variable models, while the model including variables of CP, LIG and ADF performed the best in BMP prediction $\left(\mathrm{R}^{2}=0.999, \mathrm{p}=0.009-0.017\right)$ if three-variable models were compared. Among the three kinetic models used, the first order kinetic model fitted the measured BMP data best $\left(\mathrm{R}^{2}=0.996-0.998\right.$, rRMSE $=0.171-0.381)$ and deviations between measured and the first order kinetic model predicted BMPs were less than 3.0\%.

Keywords: Anaerobic digestion, Biochemical methane potential (BMP), Livestock manure, Regression model, Kinetic model

\section{Introduction}

The increase in production and concentration of intensive livestock operations along with the increased urbanization of rural regions have resulted in a greater awareness and concern for the proper storage, treatment, and utilization of livestock manure. Livestock manure is one of the main emission sources of the greenhouse gases. Manure-based methane $\left(\mathrm{CH}_{4}\right)$ has been estimated to contribute $4 \%$ of all anthropogenic $\mathrm{CH}_{4}$ (USEPA, 2006). In the years to come the quantities of manure to be handled are expected to rise sharply, especially in Asia, Africa, and America. This fact, along with the fuel value of methane, calls for urgent efforts worldwide to find ways and means to capture manure-derived methane for use as an energy source (Tauseef et al., 2013).

Anaerobic digestion (AD) of livestock manure can generate methane-rich biogas and reduce air and water pollution caused by animal manure. Therefore, AD has been considered as an environmentally sustainable solution for livestock manure management. Anaerobic digestion 
has been adopted and integrated into animal production systems over the last century, with thousands of full-scale anaerobic digesters currently operated in the world. There are approximately 244 anaerobic digesters (dairy -199 , beef- 8 , dairy and beef- 8 , poultry-6, swine39) systems operating on commercial livestock farms in the United States and most of them use animal manure as a sole feedstock (AgSTAR-EPA, 2014).

With the increasing interests in $\mathrm{AD}$ of organic materials for biogas production in the last few years, there were many efforts aiming to deepen $\mathrm{AD}$ knowledge and to broaden its application (Schittenhelm, 2008). To achieve the correct approach in operating AD processes, it is crucial to know the potential biogas production of a feeding organic mixture. This will optimize the process and management variables (Schievano et al., 2009). Anaerobic bio-gasification potential assay, also known as biochemical methane potential (BMP), can be used in evaluating biogas potential of both organic matrices composing an ingestate mixture and residual biogas in digestates. The BMP is a useful parameter commonly used for waste characterization. It determines the quantity of methane (ml/g VS) potentially produced by a waste in anaerobic conditions (Angelidaki et al., 2009; Hansen et al., 2004). But measuring BMP is a timeconsuming process, as up to 60-90 days are required as a standard incubation time (Angelidaki et al., 2009; Hansen et al., 2004; Kafle et al., 2013) and thus, is not a practical management tool at an industrial scale for anaerobic digestion optimization. Reducing this time could lead to an increased production of methane by a better control of the fermentation (Lesteur et al., 2011). Therefore, it is attractive to use faster methods to predict how much methane gas possibly to be produced from a given substrate. This is especially the case when making theoretical studies without access to laboratory facilities, or when a fast prediction of the BMP from new substrates is required. 
Mathematical models allow us to predict methane production from livestock manure without undertaking extensive and costly experiments. Models based on the composition of the waste have also been used for predicting the BMP. For instance, the Bushwel formula calculates the theoretical methane yield from the elementary chemical composition $(\mathrm{C}, \mathrm{H}, \mathrm{O}, \mathrm{N})$ determined by pyrolysis (Davidsson et al., 2007). The main problem of this formula is that biodegradable and non-biodegradable matter are both taken into account for the calculation, while only the biodegradable matter is metabolized into methane. Therefore, the methane yield is overestimated. Not only the elementary composition, but also the component composition (carbohydrates, proteins, lipids, fibers, total carbon, total nitrogen) can be input in models (Lesteur et al., 2011). For solid waste, such models have already been built (Gunaseelan, 2009; Gunaseelan, 2007; Mottet et al., 2010; Schievano et al., 2009) with satisfying performances i.e. a root mean square error of prediction (RMSEP) of $73 \mathrm{ml} \mathrm{CH}_{4} / \mathrm{g}$ VS and bias of $54 \mathrm{ml} \mathrm{CH} 4 / \mathrm{g}$ VS (Gunaseelan, 2007). Similarly, Eleazer et al. (1997) researched the connection between the cellulose, hemicellulose and lignin content of municipal residues to its anaerobic biodegradability and found that not only did the amount of lignin in the substrate influence the BMP but the chemical composition of the lignin itself played an important role as well. Determining BMPs through regression models is a relatively new methodology initiated within the last decade. Focusing only on some fresh lignocellulosic feedstock such as sorghum, napier grass and fruit, and vegetable solid wastes, relationships between biogas potential and single chemical parameters were established (Gunaseelan, 2009; Gunaseelan, 2007; Monlau et al., 2012; Triolo et al., 2011). However, regression models using chemical composition in relation to the methane recovery of different manures have not been investigated yet. 
Due to the role of microbes in the anaerobic processes, kinetic models were commonly applied to simulate anaerobic biodegradation. Like the phase of bacterial growth, biogas production rate showed a rising curve, and a decreasing curve indicated by exponential and linear equations (Gioannis et al., 2009; Kumar et al., 2004). Understanding the kinetics of methane production from feedstock(s) is important for designing and evaluating anaerobic digesters. The first order kinetic model, Gompertz equation and Chen and Hashimoto model for describing the anaerobic digestion processes of different manures have been applied successfully to anaerobic treatment using different types of reactors (Kafle \& Kim, 2013; Kafle \& Kim, 2012; Kafle et al., 2013). To the best of our knowledge, no literature has reported the kinetics of methane production from the different livestock manures under the same test conditions using these three kinetic models.

Anaerobic biodegradation is a complex process. Therefore, the BMP determination procedure should be carefully planned, anaerobic optimal growth conditions should be secured and results should be carefully evaluated (Angelidaki \& Sanders, 2004).The source of inoculum used plays a role in the biogas production rate and the biogas potential of substrates used. Similarly, the size of the digester and the loading amount used will have an effect on biogas production (Browne \& Murphy, 2013). Thus, the same substrates might show different BMPs based on the tests conditions. Although, there is a number of literature reporting the methane productions from different livestock manures, there is a lack of research focusing on evaluating methane potential of several livestock manures under same anaerobic conditions (same inoculum, temperature, time, and digester size). And there is no literature presenting BMP statistical models developed and evaluated by using different livestock manures test results. Therefore, the aims of this study were (1) to compare BMPs of different livestock manures under the same conditions and to characterize the nutrients of effluents from different manures; (2) to develop single variable and multiple variable regression models based on chemical composition to predict the BMP; (3) to evaluate the different kinetic models for predicting the BMP and to determine kinetic parameters using the BMP test results. 


\section{Methods}

\subsection{Manures and inoculum used}

Fresh solid dairy manure (DM) was obtained from a commercial dairy farms located in Jerome, Idaho (ID). Fresh horse manure (HM) was obtained from a local horse barn in Twin falls, ID. Goat manure (GM) of one week old was obtained from a commercial goat farm in Twin Falls, ID. Solid chicken manure (CM) of around one week old was obtained from a local chicken farm in Twin Falls, ID. Swine manure (SM) was obtained from a commercial swine farm in Kimberly, ID. The collected manures were stored at $4^{\circ} \mathrm{C}$ for a week before it was used. The anaerobic inoculum was obtained from a dairy manure based anaerobic digester operated on a commercial dairy in Jerome, ID. The characteristics of the DM, HM, GM, CM, SM and the inoculum used for the tests are shown in Table 1.

\subsection{Test setup and design}

Batch AD tests were conducted in duplicate using 0.5 L Duran glass bottles (hereafter called digesters) with a working volume of $0.2 \mathrm{~L}$. The batch digesters were maintained at $36.5^{\circ} \mathrm{C}$ in a temperature-controlled incubator (Model IB-01E/11E/21E, Lab Companion, Joe Tech Co. Ltd., South Korea). The manure loading factor was $3.5 \mathrm{~g}$ VS/L and a feed to inoculum ratio (F/I) was maintained 0.5 in all the batch digesters. The F/I ratio was based on the initial VS of the manure and inoculum. After adding the designed amounts of inoculum and manure in the batch digesters, the working volume of $0.2 \mathrm{~L}$ was made up using tap water. The headspace of each digester was purged with nitrogen gas (99.9\% purity) for approximately 2 minutes to ensure anaerobic conditions. Then digesters were tightly closed with silicone stopper and screw caps. Each digester was mixed manually for one minute daily just before measuring the headspace gas pressures. Assays with inoculums alone were also used as controls. Biogas and methane produced from the inoculums (controls) were subtracted from the sample assays. The results thus represent only the gas production from the manure. 


\subsection{Biogas and methane measurement and calculations}

The daily biogas production of each digester was calculated from the headspace volume and pressure of the digester, as previously established by Kafle and Kim (2013) and Kafle et al. (2013). Methane concentration $\left(\mathrm{CH}_{4}, \%\right)$ and carbon dioxide concentration $\left(\mathrm{CO}_{2}, \%\right)$ in the biogas were analysed by using a gas chromatograph (GC) (Agilent 7980A) equipped with both thermal conductivity detector (TCD) and flame ionization detector (FID). A capillary column of dimension $60 \mathrm{~m} \times 0.32 \mathrm{~mm}$ was used in the GC. The column temperature was set at $35^{\circ} \mathrm{C}$ and held for $4 \mathrm{~min}$ for injection, then programmed at $30^{\circ} \mathrm{C} / \mathrm{min}$ to $150^{\circ} \mathrm{C}$ and held for $0.25 \mathrm{~min}$. Helium gas was used as a carrier gas $(3.0 \mathrm{~mL} / \mathrm{min})$ and the $\mathrm{GC}$ was calibrated by using a certified gas containing 60\% methane, 30\% carbon dioxide and 10\% nitrogen. Biogas was sampled, using $5 \mathrm{~mL}$ gas tight syringes (Agilent Technologies, CA), from each digester's headspace for composition analysis. The measured biogas and methane volumes were adjusted to the volumes at standard temperature $\left(0^{\circ} \mathrm{C}\right)$ and pressure $(1 \mathrm{~atm})(\mathrm{VDI}-4630,2006)$. The biogas production rates and methane content changed considerably as the batch digestion progressed. The methane content was measured daily during day 1 to day 5,3 times per week during day 6 to day 15, 2 times per week during day 16 to day 28 and 1 time per week during day 29 to day 45 . The methane content on intermediate days was linearly interpolated by the INTERP1 function in Matlab software R2011b (7.13.0.564).The corrected daily methane contents and the weighted average methane contents over the digestion period were calculated following the method described by Kafle and Kim (2013).

$$
\mathrm{CH}_{4 \text { Corr }}=\frac{\mathrm{C}_{\mathrm{CH}_{4}} \times 100}{\mathrm{C}_{\mathrm{CH}_{4}}+\mathrm{C}_{\mathrm{CO}_{2}}}
$$

where 
$\mathrm{CH}_{4}$ Corr $=$ corrected methane content in the dry gas (\% by volume),

$\mathrm{C}_{\mathrm{CH} 4}=$ measured methane content in the gas (\% by volume $)$,

$\mathrm{C}_{\mathrm{CO} 2}=$ measured carbon dioxide content in the gas ( $\%$ by volume $)$.

$\mathrm{CH}_{4 \text { Corr, WA }}(\%)=\frac{\sum_{\mathrm{i}=1}^{\mathrm{n}} \mathrm{BP}_{\mathrm{i}} \times \mathrm{CH}_{4 \text { Corr }, \mathrm{i}}}{\sum_{\mathrm{i}=1}^{\mathrm{n}} \mathrm{BP}_{\mathrm{i}}}$

Based on the weighted average corrected methane content and the interpolated data, the standard deviation $(\sigma)$ was calculated in Excel software 2007 as follows:

$\sigma=\sqrt{\frac{\sum\left(\mathrm{CH}_{4 \mathrm{Corr}_{\mathrm{i}}}-\mathrm{CH}_{4 \text { Corr } \mathrm{WA}}\right)^{2}}{\mathrm{n}-1}}$

where,

$\mathrm{BP}_{\mathrm{i}}=$ biogas production on day $\mathrm{i}$,

$\mathrm{CH}_{4}$ Corr, $\mathrm{i}=$ corrected methane content on day $\mathrm{i}$,

$\mathrm{n}=$ number of observations.

At the end of the experiment, mass removal in the form of biogas (biogas removed, BR) (Kafle et al., 2012) and TS and VS removals were also calculated using the method described by Kafle et al. (2013).

\subsection{Analytical methods}

Total solids and VS were determined in the well-mixed samples in triplicate following Standard Methods (APHA, 1998). A pH/mV meter (water quality meter pH kit-850086, SperScientific, Taiwan) was used to measure pH. Soluble chemical oxygen demand (SCOD), total chemical oxygen demand (TCOD), total ammonia nitrogen (TAN), total Kjehldahl nitrogen 
$(\mathrm{TKN})$, total nitrogen $(\mathrm{TN}), \mathrm{NO}_{2}{ }^{-}-\mathrm{N}+\mathrm{NO}_{3}{ }^{-}-\mathrm{N}$, total potassium $(\mathrm{K})$, and phosphate $\left(\mathrm{PO}_{4}{ }^{3-}\right)$ were analyzed using a spectrophotometer (DR 5000, Hach, USA). The analyses of crude fibre (CF), crude protein (CP), total fat (ether extract) (TF), ash and nitrogen free extract (NFE) were performed following the methods detailed in (AOAC, 1990). Total carbohydrate (TC) was calculated by using $\mathrm{CF}$ and NFE values $(\mathrm{TC}=\mathrm{CF}+\mathrm{NFE})$. The analyses of acid detergent fibre (ADF) were carried out following the methods of Goering and Van Soest (1970). The total volatile fatty acids (TVFA), alkalinity and TVFA/alkalinity ratio ((FOS/TAC - in German: Flüchtige Organische Säuren/Totales Anorganisches Carbonat) were measured by titration using a Biogas Titration Manager (Product \# R41T114, Hach) (Kafle \& Kim, 2011).

\subsection{Statistical models to predict BMP}

\subsubsection{Linear regression models}

In this study, nutrient compositions such as TC, CP, TF, LIG and ADF were used to develop simple and multiple regression models for predicting methane potentials. Equation (4) represents a single variable linear regression equation and Equations (5) and (6) are multiple variable linear regression equations.

$$
\begin{aligned}
& Y=b_{0}+b_{1} \cdot X_{1} \\
& Y=b_{0}+b_{1} \cdot X_{1}+b_{2} \cdot X_{2} \\
& Y=b_{0}+b_{1} \cdot X_{1}+b_{2} \cdot X_{2}+b_{3} \cdot X_{3}
\end{aligned}
$$

where $\mathrm{Y}$ is the response variable, $b_{0}$ represents the $\mathrm{Y}$-intercept, $X_{1}, X_{2}$, and $X_{3}$ are explanatory variables and $b_{1}, b_{2}$ and $b_{3}$ are their regression coefficients. 


\subsubsection{Kinetic models}

\subsubsection{First order kinetic model}

First order kinetic model is the simplest model, however, this model does not predict the conditions for maximum biological activity and system failures. Hydrolysis is often assumed to be the rate-limiting step in anaerobic digestion and based on this, researchers have modeled batch BMP data using first-order hydrolysis models and obtained valuable interpretations about hydrolysis kinetics. The following is a basic first order kinetic equation:

$$
\frac{\mathrm{d} C}{d t}=-K C
$$

where

$\mathrm{K}=$ first order disintegration rate constant $(1 / \mathrm{d})$,

$\mathrm{t}=$ digestion time (day),

$\mathrm{C}=$ biodegradable substrate concentration (VS or COD).

Rearranging equation (7) and integrating for time $=0$ to $t$ days gives equation (8)

$\ln \left[\frac{\mathrm{C}_{\mathrm{t}}}{\mathrm{C}_{0}}\right]=-K t$

Or

$\left[\frac{\mathrm{C}_{\mathrm{t}}}{\mathrm{C}_{0}}\right]=e^{-K t}$ 
It is easier to derive the model by using the gas measurement instead of measuring $\mathrm{C}$, which is difficult. The relationship between VS or COD and methane production can be described by equation (9):

$$
\frac{\mathrm{C}_{\mathrm{t}}}{\mathrm{C}_{0}}=\frac{G_{o}-G(t)}{G_{0}}
$$

Substituting equation (8) into equation (9) produces equation (10)

$$
\mathrm{G}(\mathrm{t})=\mathrm{G}_{0} \times\left(1-\mathrm{e}^{(-\mathrm{Kt})}\right)
$$

where

$\mathrm{C}_{\mathrm{t}}=$ final or outlet substrate concentration $(\mathrm{mg} / \mathrm{L})$,

$\mathrm{C}_{\mathrm{o}}=$ initial or inlet substrate concentration $(\mathrm{mg} / \mathrm{L})$,

$\mathrm{G}(\mathrm{t})=$ cumulative methane yield at digestion time $\mathrm{t}(\mathrm{mL} / \mathrm{g} \mathrm{VS})$,

$\mathrm{G}_{\mathrm{o}}=$ methane potential of the substrate $(\mathrm{mL} / \mathrm{g} \mathrm{VS})$,

$\mathrm{K}=$ methane production rate constant (first order disintegration rate constant) (1/day).

Equation (10) provides an accurate representation of the BMP results when (a) hydrolysis is the rate-limiting step, and (b) the maximum methane production at the infinite time $\left(\mathrm{G}_{0}\right)$ represents the total yield of hydrolysable VS at the beginning of the tests (Parameswaran \& Rittmann, 2012).

\subsubsection{Modified Gompertz model}

The Gompertz model, which was set on an exponential relationship between specific growth rate and population density, was originally developed to fit human mortality data and it has also been used to predict organ growth (Causton, 1977). Gibson et al. (1987) modified the Gompertz model to a function that describes cell density during bacterial growth periods in terms 
of exponential growth rates and lag phase duration. An assumption of methane production rate in a batch digester corresponding to the specific growth rate of methanogenic bacteria led to equation (11) (Lay et al., 1998). This equation has been identified as a good empirical non-linear regression model and commonly used in the simulation of methane accumulation.

$\mathrm{G}(\mathrm{t})=\mathrm{G}_{0} \cdot \exp \left\{-\exp \left[\frac{\mathrm{R}_{\max } \cdot \mathrm{e}}{\mathrm{G}_{0}}(\lambda-\mathrm{t})+1\right]\right\}$

where

$\mathrm{R}_{\max }=$ maximum biogas production rate $(\mathrm{mL} / \mathrm{d})$,

$\lambda=$ lag phase (day),

$\mathrm{t}=$ time $($ day $)$

$\mathrm{e}=\exp (1)=2.7183$.

The lag phase represents the minimum time taken to produce biogas or taken for bacteria to acclimatize to the environment. The maximum methane production rate $\left(\mathrm{R}_{\mathrm{m}}\right)$ describes specific growth rate of methanogenic bacteria. The higher the $\mathrm{R}_{\mathrm{m}}$ is, the higher the biogas production rate is.

\subsubsection{Chen and Hashimoto model}

Built on both fundamental biochemical principles and the Contois model (Contois, 1959), the Chen and Hashimoto model (Chen \& Hashimoto, 1978; Chen \& Hashimoto, 1980) described in equation (12) has been recognized as a reliable tool in predictions regarding digestion of wastes with substantial TS content (Fongsatitkul et al., 2012). 


$$
\frac{\mathrm{C}_{\mathrm{t}}}{\mathrm{Co}}=\frac{\mathrm{K}_{\mathrm{CH}}}{\mathrm{HRT} \times \mu_{\mathrm{m}}+\mathrm{K}_{\mathrm{CH}}-1}
$$

where

HRT = digestion time or hydraulic retention time (days),

$\mathrm{K}_{\mathrm{CH}}=$ Chen and Hashimoto kinetic constant (dimension less),

$\mu_{\mathrm{m}}=$ maximum specific growth rate of microorganisms (1/day).

Substituting equation (9) into equation (12) results in equation (13)

$$
\frac{G_{o}-G(t)}{G_{o}}=\frac{K_{C H}}{H R T \times \mu_{m}+K_{C H}-1}
$$

The equation (13) can be converted to equation (14).

$$
G(\mathrm{t})=G_{o}\left(1-\frac{K_{C H}}{H R T \times \mu_{m}+K_{C H}-1}\right)
$$

The Chen and Hashimoto model has obtained satisfied results for both the continuous and batch anaerobic digestion processes (Kafle \& Kim, 2012; Kafle et al., 2013).

2.6. Statistical analysis, model parameters determination and evaluation

The Analysis of Variance (ANOVA) and least significant difference (LSD) analysis were performed at the significance $(\alpha)$ levels of 5\% and 1\% (Kafle \& Kim, 2013).

Single and multiple variable regression analyses were performed using Excel Software, 2007. All the parameters of the three kinetic models were determined using nonlinear regressions. Nonlinear regression models were established by the 'Solver' function in Excel Software, 2007. The model predicted methane yields were plotted with the measured methane yields using an excel program. 
To evaluate the models statistical indicators such as the coefficient of determination $\left(\mathrm{R}^{2}\right)$ and relative root mean square error (rRMSE) based on equation (15) were calculated (Bhattarai et al., 2012).

$$
\operatorname{rRMSE}=\left(\frac{1}{m} \sum_{j=1}^{m}\left(\frac{d_{j}}{Y_{j}}\right)^{2}\right)^{\frac{1}{2}}
$$

where $d_{j}$ is the deviation between the $\mathrm{j}^{\text {th }}$ measured and the predicted values, $m$ is the number of data points and $Y_{j}$ is the $\mathrm{j}^{\text {th }}$ measured value.

\section{Results and discussion}

\subsection{Batch anaerobic digestion test results}

The biogas production rates for different livestock manures are presented in Fig.1. Fig. 2 shows cumulative biogas yields (mL/g VS) and methane contents in the biogas produced from different livestock manures. Biogas production started immediately on the first day in all the digesters. The peak values of daily biogas production rates were calculated to be $25,19,18,47$ and $64 \mathrm{~mL} / \mathrm{g}$ VS days after 5, 7, 7, 6 and 3 days of digestion from DM, HM, GM, CM and SM, respectively. Approximately 90\% of the biogas yield was obtained within 28, 37, 44, 18 and 17 days of digestion from DM, HM, GM, CM and SM, respectively. The technical digestion time ( $\mathrm{T}_{80-90}$ ) for biogas production (the time period for $80 \%$ to $90 \%$ of the maximum biogas production) was calculated to be in the range of 19-28, 27-37, 31-44, 13-18 and 12-17 days for DM, HM, GM, CM and SM, respectively (Table 2). The technical digestion time can be used as a HRT for continuous anaerobic digestion of these manures (Kafle et al., 2013). At the end of 90 days, the average biogas yields from the digesters were calculated to be $295,222,242425$, and $495 \mathrm{~mL} / \mathrm{g}$ VS for DM, HM, GM, CM and SM, respectively. The LSD values for biogas yield were calculated to be 35 and $51 \mathrm{~mL} / \mathrm{g}$ VS added at significance levels of $5 \%$ and $1 \%$, 
respectively (Table 3). No significant difference was found in the biogas potential of HM and GM but biogas potential of all other manures were significantly different from each other $(\mathrm{p}<0.01)$.

Methane contents (\%) increased till day 15 in all the digesters and thereafter remains almost constant (Fig. 2b). The weighted average methane contents of the biogas produced from the DM, HM, GM, CM and SM were $69.1 \%, 70.1 \%, 65.8 \%, 61.1 \%$ and $65.3 \%$, respectively. The LSD values for the methane content were calculated to be $0.7 \%$ and $1.0 \%$ at significance levels of $5 \%$ and $1 \%$, respectively. Statistically, significant differences $(\mathrm{p}<0.01)$ in average methane contents between different manures were found. Based on the methane contents, the average methane yields from DM, HM, GM, CM and SM at the end of 90 days were calculated to be 204, 155, 159, 259 and 323 mL/g VS, respectively. Statistically, SM showed significantly higher $(\mathrm{p}<0.01)$ methane potential compared to other manures. Theoretically, the complete anaerobic digestion of TC, TP and TF produces 375, 480 and $1001 \mathrm{~mL} / \mathrm{g}$ VS methane, respectively (VDI4630, 2006). Thus higher TP and TF contents in SM may be the reason for highest methane potential among all the manures. Asam et al. (2011) and Kafle et al. (2012) reported almost the same (325-330 mL/g VS) methane potential for SM as in our study but Browne et al. (2013) reported a lower BMP (70-99 mL/g VS). Triolo et al. (2011) reported BMP in the range of 197$417 \mathrm{~mL} / \mathrm{g}$ VS for different swine and cattle manures. Similarly, the BMP of HM in our study falled in the range (68-273 $\mathrm{mL} / \mathrm{g}$ VS) as reported by Wartell et al. (2012).

The calculated BR and VS removal at the end of the 90 days digestion period are shown in Table 2. Theoretically, the calculated biogas mass removal should be higher than the measured VS removal (Richards et al., 1991) but in our study BR was always lower than VS removal (Table 2). Kafle et al. (2012) and Liu et al. (2009) also reported lower BR than VS removal. The 
measured VS removals showed good correlation $\left(\mathrm{R}^{2}=0.929, \mathrm{p}=0.008\right.$, relation is not shown) with BR. Similar to our study results, Kafle et al. (2012) also reported good correlation ( ${ }^{2}$ $>0.900$ ) between VS removal and BR. The VS removals were calculated to be 58.6,52.9,46.4,81.4 and 81.4\% for the DM, HM, GM, CM and SM, respectively. No significant difference in VS removal was found among the DM, HM and GM $\left(\mathrm{LSD}_{0.05}=12 \%, \mathrm{LSD}_{0.01}=\right.$ 18\%). Similarly, the CM and SM also showed no significant difference in VS removal. But VS

removal for the CM and SM was significantly higher $(\mathrm{p}<0.01)$ than that of the DM, HM and GM. The VS removals showed linear relationships with LIG contents and BMP $\left(\mathrm{G}_{0}\right)$. The correlations of VS removals with LIG contents and $\mathrm{G}_{0}$ are shown in equations (16) and (17), respectively.

VS removal $(\%)=88.3-2.415 \mathrm{LIG}\left(\mathrm{R}^{2}=0.780, \operatorname{Adj} . \mathrm{R}^{2}=0.707, \mathrm{p}=0.047, \mathrm{SE}=9\right)$

$\mathrm{VS}$ removal $(\%)=17.0+0.214 \mathrm{G}_{0}\left(\mathrm{R}^{2}=0.873, \operatorname{Adj} . \mathrm{R}^{2}=0.831, \mathrm{p}=0.020, \mathrm{SE}=7\right)$

\subsection{Effluent characterization}

The initial and final characteristics of the digester contents are shown in Table 4. Final $\mathrm{pH}$ decreased for the DM, HM and GM but remained constant for the CM and increased for the SM (Table 3). The calculated LSD was 0.05 at $\alpha=0.05$ and 0.07 at $\alpha=0.01$ (Table 3). No significant difference was observed in the final $\mathrm{pH}$ for the $\mathrm{DM}, \mathrm{HM}$ and $\mathrm{GM}$ but final $\mathrm{pH}$ of the $\mathrm{CM}$ and SM was significantly higher $(\mathrm{p}<0.05)$ than the other three manures. The TVFA concentration decreased and TA increased after anaerobic digestion for all the manures. The lowest and highest TVFA concentrations were measured for the GM and SM, respectively. No significant difference in TVFA concentration was observed for the DM, HM, GM and CM but it was significantly higher for the SM compared to the other four manures (Table 3 and Table 4). Final alkalinity concentration for the CM and SM was significantly higher than the other three 
manures $(\mathrm{p}<0.01)$, due to a higher content of $\mathrm{CP}$ in these two manures as opposed to other manures. A higher alkalinity concentration was the reason for the higher final $\mathrm{pH}$ of the $\mathrm{CM}$ and $\mathrm{SM}$ versus other manures.The degradation of $\mathrm{CP}$ will increase the ammonical nitrogen concentrations (Herrmann et al., 2011), resulting in an increase in the alkalinity and $\mathrm{pH}$ of the manure. The GM and SM effluents showed the highest TAN concentrations while the CM effluent showed the lowest TAN concentration. No significant difference in initial and final TAN concentrations were observed for the DM and CM but TAN concentrations significantly increased $(\mathrm{p}<0.05)$ for the other three manures. The highest final TKN concentration was recorded for the SM followed by the CM. The TKN concentrations of the HM and SM were significantly decreased $(\mathrm{p}<0.05)$ but no significant difference was found for the other three manures. The inorganic nitrogen $\left(\mathrm{NO}_{2}-\mathrm{N}+\mathrm{NO}_{3}-\mathrm{N}\right)$ decreased significantly $(\mathrm{p}<0.01)$ for all the manures after anaerobic digestion. Potassium and $\mathrm{PO}_{4}{ }^{3-}$ concentrations significantly increased $(\mathrm{p}<0.05)$ for all the manures after anaerobic digestion. The highest $\mathrm{K}$ and $\mathrm{PO}_{4}{ }^{3-}$ concentrations were recorded for the SM and CM, respectively. No significant difference in the final $\mathrm{K}$ concentrations of the DM, HM, GM and CM was found but the SM effluent showed significantly higher $(\mathrm{p}<0.01) \mathrm{K}$ concentration than the other four manures. No significant difference was found in the final TCOD concentrations for all the manures. Similarly, all the manures (except the HM) showed no significant difference in the final SCOD concentration.

\subsection{Results of regression and kinetic analysis}

Linear regression models were developed to predict methane potential $\left(\mathrm{G}_{0}\right)(\mathrm{mL} / \mathrm{g} \mathrm{VS})$ using variables (manure compositions) including TC, CP, TF, LIG and ADF. The simple and multiple regression models developed in this study are listed in Table 5.Using the single variables, the most significant $\mathrm{G}_{0}$ models $(\mathrm{p}=0.026)$ were predicted by LIG, while other variables showed 
poor regression $\left(R^{2}=0.347-0.668\right)$ and lower significance levels $(p=0.091-0.296)$. The $R^{2}$ between $\mathrm{G}_{0}$ and LIG was 0.851 and the deviations of the measured methane potentials from the predicted methane potential were calculated in the range of $11.4 \pm 3.7 \%$ (Table 5). Triolo et al. (2011) reported a higher $\mathrm{R}^{2}$ value (0.908) between $\mathrm{G}_{0}$ and LIG for manures but a lower $\mathrm{R}^{2}$ value (0.763) for energy crops. (Triolo et al. (2011)) explained that LIG affects BMP more significantly in energy crops than in animal manure because the cell walls of crops are protected by an intact lignocellulose matrix whereas, in animal manure, parts of this matrix are broken by animal digestion systems. The results of the simple linear regression also confirms that LIG controls VS destruction most significantly, which makes it possible to provide fine correlations between $\mathrm{G}_{0}$ and LIG (Triolo et al., 2011). The $\mathrm{G}_{0}$ is negatively correlated with LIG because LIG is not degradable. In contrast to our tests results, a very weak correlation $\left(R^{2}=0.334-0.460\right)$ was reported by Xu et al. (2014) and Kandel et al. (2013) when using lignocellulosic biomass and reed canary grass, respectively.

Multiple regressing models using two and three variables were developed. The $\mathrm{R}^{2}$ values were improved by the multiple regressing models and deviations between the measured and the multiple regressing model predicted $\mathrm{G}_{0}$ were decreased compared to the linear regression models (Table 5). Similarly, Xu et al. (2014) also reported that their models including multiple feed stock characteristics had better regression results. Considering $\mathrm{R}^{2}$, p-value $(<0.1$ for each variable) and deviation, the model with the combination of two variables of TC and TF showed the best $\mathrm{G}_{0}$ regression $\left(\mathrm{R}^{2}=0.913\right.$ and $\mathrm{p}=0.068-0.075$, deviations $\left.=7.3 \pm 5.0 \%\right)$ among the two variable models. Similarly, the model with the combination of CP, LIG, and ADF showed the best $\mathrm{G}_{0}$ regression $\left(\mathrm{R}^{2}=0.999\right.$ and $\mathrm{p}=0.009-0.017$, deviations $\left.=0.3 \pm 0.2 \%\right)$ among models with three variables followed by the combination of TC, CP and TF $\left(\mathrm{R}^{2}=0.999, \mathrm{p}=0.045-0.073\right.$, 
deviations $=1.0 \pm 1.1 \%)$ and the combination of $\mathrm{TC}$, TF and $\mathrm{ADF}\left(\mathrm{R}^{2}=0.999, \mathrm{p}=0.042-0.081\right.$, deviations $=1.1 \pm 1.0 \%)($ Table 5$)$.

Table 6 summarizes the estimated parameters of the studied kinetic models. Among the three models used, the first order kinetic model showed the lowest difference (0-2.5\%) followed by the modified Gompertz model (2.0-4.6\%). Chen and the Hashimoto model showed the highest difference between the measured and predicted methane yield (6.4-10.7\%). The low deviations obtained between the theoretical and experimental values (nearly equal to or lower than 10\%) suggest that all three proposed models predict the behavior of the reactors very accurately (Raposo et al., 2009). No lag phase $(\lambda)$ was recorded for each manure. The use of active inoculum and the availability of soluble degradable materials in each of the livestock manures can be the reason for zero lag phase. The $\mathrm{k}, \mathrm{R}_{\mathrm{m}}, \mu_{\mathrm{m}}$ parameters of different models showed similar relation with the different manures (Table 1 and Table 6). These parameters showed an increasing trend for the decrease in LIG contents within the manure. The highest $\mathrm{k}, \mathrm{R}_{\mathrm{m}}$ and $\mu_{\mathrm{m}}$ values were estimated for the SM followed by the CM and the lowest was for the GM. No significant difference in $\mathrm{k}$ and $\mu_{\mathrm{m}}$ values were found for the CM and $\mathrm{SM}$ but the predicted $\mathrm{R}_{\mathrm{m}}$ value for the SM was significantly higher than that for the CM. To evaluate the soundness of the kinetic model results, the predicted values of methane yields were plotted against the measured values as shown in Fig. 3, Fig. 4 and Fig. 5, respectively for the first order kinetic model, modified Gompertz model and Chen and Hashimoto model, respectively. The statistical indicators (rRMSE and $\mathrm{R}^{2}$ values) are also shown in respective Figures. The lower rRMSE (0.171-0.381) and higher $\mathrm{R}^{2}$ value $(0.996-0.998)$ were calculated for the first order kinetic model followed by the modified Gompertz model ( $\mathrm{rRMSE}=0.157-0.616, \mathrm{R}^{2}=0.992-0.995$ ). Thus, based on the kinetic study results (difference between predicted and measured methane yield, 
and statistically indicators) the first order kinetic model was found to be the best model to fit the measured methane yields. Zero lag phase for all the manure used in our study was one of the main reason why that first order kinetic model showed a better fit than the modified Gompertz model. In the BMP tests conducted by Kafle and Kim (2013) and Kafle et al. (2013) a lag phase was reported for their tested substrates and they reported the modified Gompertz model was a better model to predict the BMP compared to the first order kinetic model.

\section{Conclusions}

The BMP and VS removal for five different livestock manures were measured in the ranges of $155-323 \mathrm{~mL} / \mathrm{g}$ VS and 46.4-81.4\%, respectively. The highest and lowest BMP was measured for the SM and the HM, respectively. The hydraulic retention time for anaerobic digestion under mesophilic temperatures are suggested in the ranges of 19-28, 27-37, 31-44, 1318, 12-17 days for DM, HM, GM, CM and SM, respectively. Among the five different manures used the CM digester effluents showed higher nitrogen and phosphorous concentrations and the SM digester effluents showed higher potassium concentrations than other manures. The HM digester effluents showed the lowest nitrogen, phosphorus and potassium concentrations. LIG based model was the best single variable model and the TC and TF based model was the best two variable model in terms of predicting BMP. The CP, LIG and ADF based model showed the best among the three variable models for predicting BMP. Among the three kinetic models used, the first order kinetic model was found to be the best model $\left(\mathrm{R}^{2}=0.996-0.998\right.$, deviations $\left.<3 \%\right)$ for predicting BMP for livestock manures.

\section{Acknowledgements}


Funding for this project was provided, in part, by the Idaho Agricultural Experiment

Station and the USDA-NIFA.

\section{References}

AgSTAR-EPA. 2014. Anaerobic Digester Database, Environmental Protection Agency, US.

Angelidaki, I., Alves, M.M., Bolzonella, D., Borzacconi, L., Campos, J.L., Guwy, A., Kalyuzhnyi, S., Jenicek, P., Van Lier, J.B. 2009. Defining the biomethane potential (BMP) of solid organic wastes and energy crops: a proposed protocol for batch assays. Water Sci. Technol. 59(5), 927-34.

Angelidaki, I., Sanders, W. 2004. Assessment of the anaerobic biodegradability of macropollutants. Rev. Environ. Sci. Biotechnol. 3(2), 117-129.

AOAC. 1990. Official methods of analysis. 15 ed. Association of Official Analytical Chemists (AOAC), Washington, DC.

APHA. 1998. Standard methods for the examination of water and wastewater. 20th ed. American Publich Health Association (APHA), Washington, DC.

Asam, Z.U.Z., Poulsen, T.G., Nizami, A.S., Rafique, R., Kiely, G., Murphy, J.D. 2011. How can we improve biomethane production per unit of feedstock in biogas plants? Appl. Energy 88(6), 2013-2018.

Bhattarai, S., Oh, J.H., Euh, S.H., Krishna Kafle, G., Hyun Kim, D. 2012. Simulation and model validation of sheet and tube type photovoltaic thermal solar system and conventional solar collecting system in transient states. Sol. Energ. Mat. Sol. C. 103, 184-93.

Browne, J.D., Allen, E., Murphy, J.D. 2013. Evaluation of the biomethane potential from multiple waste streams for a proposed community scale anaerobic digester. Environ. Technol. 34(13-14), 2027-38.

Browne, J.D., Murphy, J.D. 2013. Assessment of the resource associated with biomethane from food waste. Appl. Energy 104, 170-77.

Causton, D.R. 1977. A biologist's mathematics. Edward Arnold, London.

Chen, Y.R., Hashimoto, A.G. 1978. Kinetics of methane fermentation. Biotechnol. Bioeng. Symp. Dept. of Agriculture, Clay Center, NE, US.

Chen, Y.R., Hashimoto, A.G. 1980. Substrate utilization kinetic model for biological treatment process. Biotechnol. Bioeng. 22(10), 2081-95.

Contois, D.E. 1959. Kinetics of bacterial growth: Relationship between population density and specific growth rate of continuous cultures. J. General. Microb. 21(1), 40-50.

Davidsson, A., Gruvberger, C., Christensen, T.H., Hansen, T.L., Jansen, J.1.C. 2007. Methane yield in source-sorted organic fraction of municipal solid waste. Waste Manage. 27(3), 406-14.

Eleazer, W.E., Odle, W.S., Wang, Y.S., Barlaz, M.A. 1997. Biodegradability of municipal solid waste components in laboratory-scale landfills. Environ. Sci. Technol. 31(3), 911-17.

Fongsatitkul, P., Elefsiniotis, P., Wareham, D.G. 2012. Two-phase anaerobic digestion of the organic fraction of municipal solid waste: estimation of methane production. Waste Manage. Res. 30(7), 720-26.

Gibson, A.M., Bratchell, N., Roberts, T.A. 1987. The effect of sodium chloride and temperature on the rate and extent of growth of Clostridium botulinum type A in pasteurized pork slurry. J. Appl. Bacteriol. 62(6), 47990.

Gioannis, G.D., Muntoni, A., Cappai, G., Milia, S. 2009. Landfill gas generation after mechanical biological treatment of municipal solid waste: Estimation of gas generation rate constants. Waste Manage. 29(3), 1026-34.

Goering, H.K., Van Soest, P.J. 1970. Forage fiber analyses (apparatus, reagents, prcedures, and some applications). in: USDA Agr Handb;.

Gunaseelan, V.N. 2009. Predicting ultimate methane yields of Jatropha curcus and Morus indica from their chemical composition. Bioresour. Technol. 100(13), 3426-29.

Gunaseelan, V.N. 2007. Regression models of ultimate methane yields of fruits and vegetable solid wastes, sorghum and napiergrass on chemical composition. Bioresour. Technol. 98(6), 1270-77.

Hansen, T.L., Schmidt, J.E., Angelidaki, I., Marca, E., Jansen, J.1.C., Mosbæk, H., Christensen, T.H. 2004. Method for determination of methane potentials of solid organic waste. Waste Manage. 24(4), 393-00.

Herrmann, C., Heiermann, M., Idler, C. 2011. Effects of ensiling, silage additives and storage period on methane formation of biogas crops. Bioresour. Technol. 102(8), 5153-61. 
Kafle, G.K., Kim, S.H. 2013. Anaerobic treatment of apple waste with swine manure for biogas production: Batch and continuous operation. Appl. Energy 103, 61-72.

Kafle, G.K., Kim, S.H. 2012. Kinetic study of the anaerobic digestion of swine manure at mesophilic temperature: a lab scale batch operation. J. Biosystems Eng. 37(4), 233-44.

Kafle, G.K., Kim, S.H. 2011. Sludge exchange process on two serial CSTRs anaerobic digestions: process failure and recovery. Bioresour. Technol. 102(13), 6815-22.

Kafle, G.K., Kim, S.H., Sung, K.I. 2012. Batch anaerobic co-digestion of Kimchi factory waste silage and swine manure under mesophilic conditions. Bioresour. Technol. 124, 489-94.

Kafle, G.K., Kim, S.H., Sung, K.I. 2013. Ensiling of fish industry waste for biogas production: a lab scale evaluation of biochemical methane potential (BMP) and kinetics. Bioresour. Technol. 127, 326-336.

Kandel, T.P., Sutaryo, S., Møller, H.B., Jørgensen, U., Lærke, P.E. 2013. Chemical composition and methane yield of reed canary grass as influenced by harvesting time and harvest frequency. Bioresour. Technol. 130, 65966.

Kumar, S., Mondal, A.N., Gaikwad, S.A., Devotta, S., Singh, R.N. 2004. Qualitative assessment of methane emission inventory from municipal solid waste disposal sites: a case study. Atmos. Environ. 38(29), 49214929.

Lay, J., Li, Y., Noike, T. 1998. Interaction between homoactogens and methanogens in lake sediments. J. Ferment. Bioeng. 86, 467-71.

Lesteur, M., Latrille, E., Maurel, V.B., Roger, J.M., Gonzalez, C., Junqua, G., Steyer, J.P. 2011. First step towards a fast analytical method for the determination of biochemical methane potential of solid wastes by near infrared spectroscopy. Bioresour. Technol. 102(3), 2280-88.

Liu, G., Zhang, R., El-Mashad, H.M., Dong, R. 2009. Effect of feed to inoculum ratios on biogas yields of food and green wastes. Bioresour. Technol. 100(21), 5103-08.

Monlau, F., Sambusiti, C., Barakat, A., Guo, X.M., Latrille, E., Trably, E., Steyer, J.P., Carrere, H.l.n. 2012. Predictive models of biohydrogen and biomethane production based on the compositional and structural features of lignocellulosic materials. Environ. Sci. Technol. 46(21), 12217-25.

Mottet, A., François, E., Latrille, E., Steyer, J.P., Déléris, S., Vedrenne, F., Carrère, H. 2010. Estimating anaerobic biodegradability indicators for waste activated sludge. Chem. Eng. J. 160(2), 488-96.

Parameswaran, P., Rittmann, B.E. 2012. Feasibility of anaerobic co-digestion of pig waste and paper sludge. Bioresour. Technol. 124, 163-68.

Raposo, F., Borja, R., Martín, M.A., Martín, A., De la Rubia, M.A., Rincón, B. 2009. Influence of inoculumsubstrate ratio on the anaerobic digestion of sunflower oil cake in batch mode: process stability and kinetic evaluation. Chem. Eng. J. 149(1), 70-77.

Richards, B.K., Cummings, R.J., White, T.E., Jewell, W.J. 1991. Methods for kinetic analysis of methane fermentation in high solids biomass digesters. Biomass Bioenergy 1(2), 65-73.

Schievano, A., Scaglia, B., D’Imporzano, G., Malagutti, L., Gozzi, A., Adani, F. 2009. Prediction of biogas potentials using quick laboratory analyses: Upgrading previous models for application to heterogeneous organic matrices. Bioresour. Technol. 100(23), 5777-82.

Schittenhelm, S. 2008. Chemical composition and methane yield of maize hybrids with contrasting maturity. Eur. J. Agron. 29(2), 72-79.

Tauseef, S.M., Premalatha, M., Abbasi, T., Abbasi, S.A. 2013. Methane capture from livestock manure. J. Environ. Manage. 117, 187-07.

Triolo, J.M., Sommer, S.G., Møller, H.B., Weisbjerg, M.R., Jiang, X.Y. 2011. A new algorithm to characterize biodegradability of biomass during anaerobic digestion: Influence of lignin concentration on methane production potential. Bioresour. Technol. 102(20), 9395-02.

USEPA. 2006. Global anthropogenic non-CO2 greenhouse gas emissions: 1990-2020. US Environmental Protection Agency, Washington, DC, USA.

VDI-4630. 2006. Fermentation of organic materials: Characterization of the substrate, sampling, collection of material data, fermentation tests. In: Verein Deutscher Ingenieure ed. VDI-Handbuch Energietechnik, Beuth Verlag GmbH, 10772 Berlin, Germany.

Wartell, B.A., Krumins, V., Alt, J., Kang, K., Schwab, B.J., Fennell, D.E. 2012. Methane production from horse manure and stall waste with softwood bedding. Bioresour. Technol. 112, 42-50.

Xu, F., Wang, Z.W., Li, Y. 2014. Predicting the methane yield of lignocellulosic biomass in mesophilic solid-state anaerobic digestion based on feedstock characteristics and process parameters. Bioresour. Technol. 173, $168-76$. 


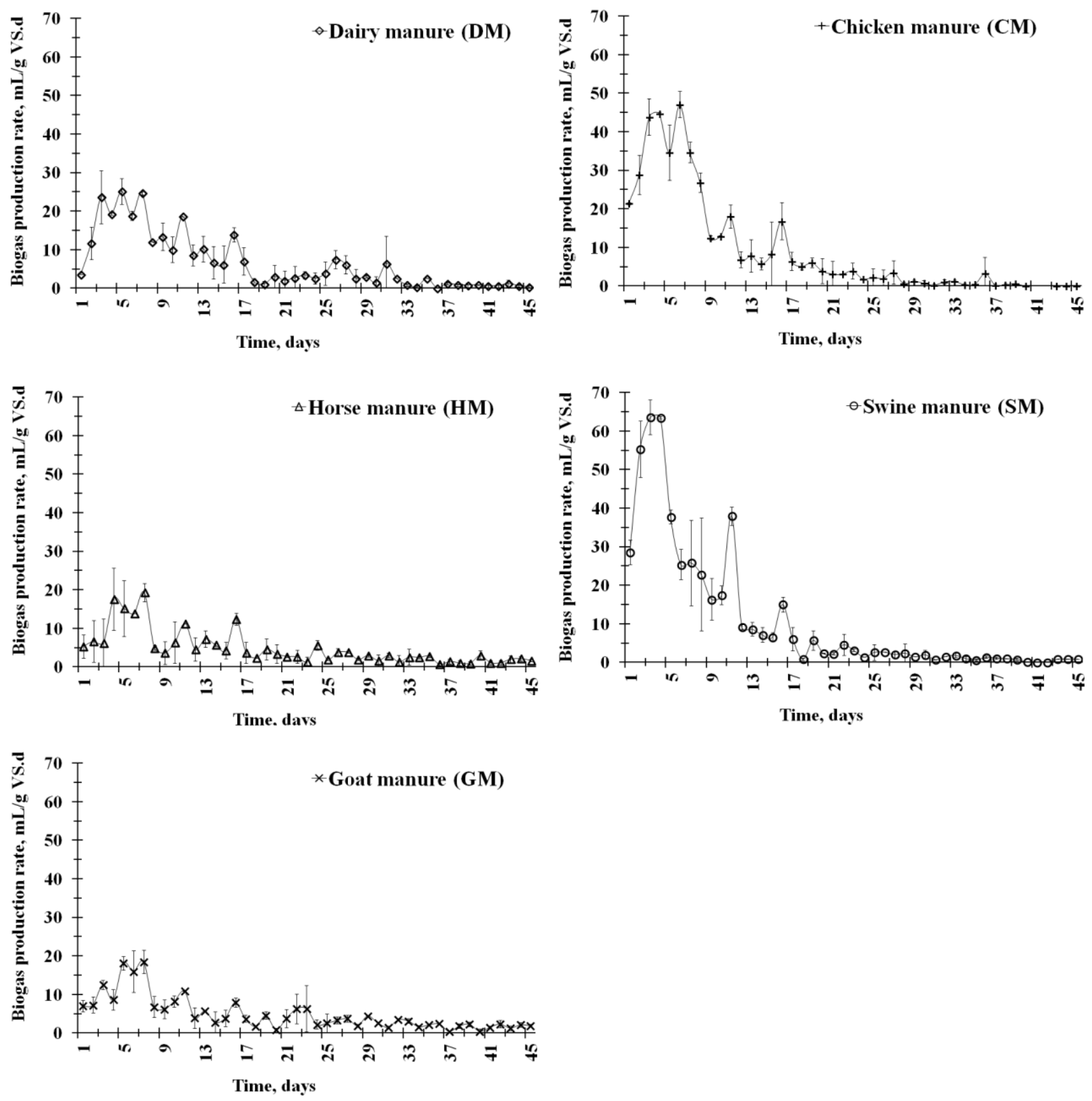

Fig.1 Daily biogas production from different manures. The values are means \pm standard deviations (vertical bars, $\mathrm{n}=3$ rd deviations). 

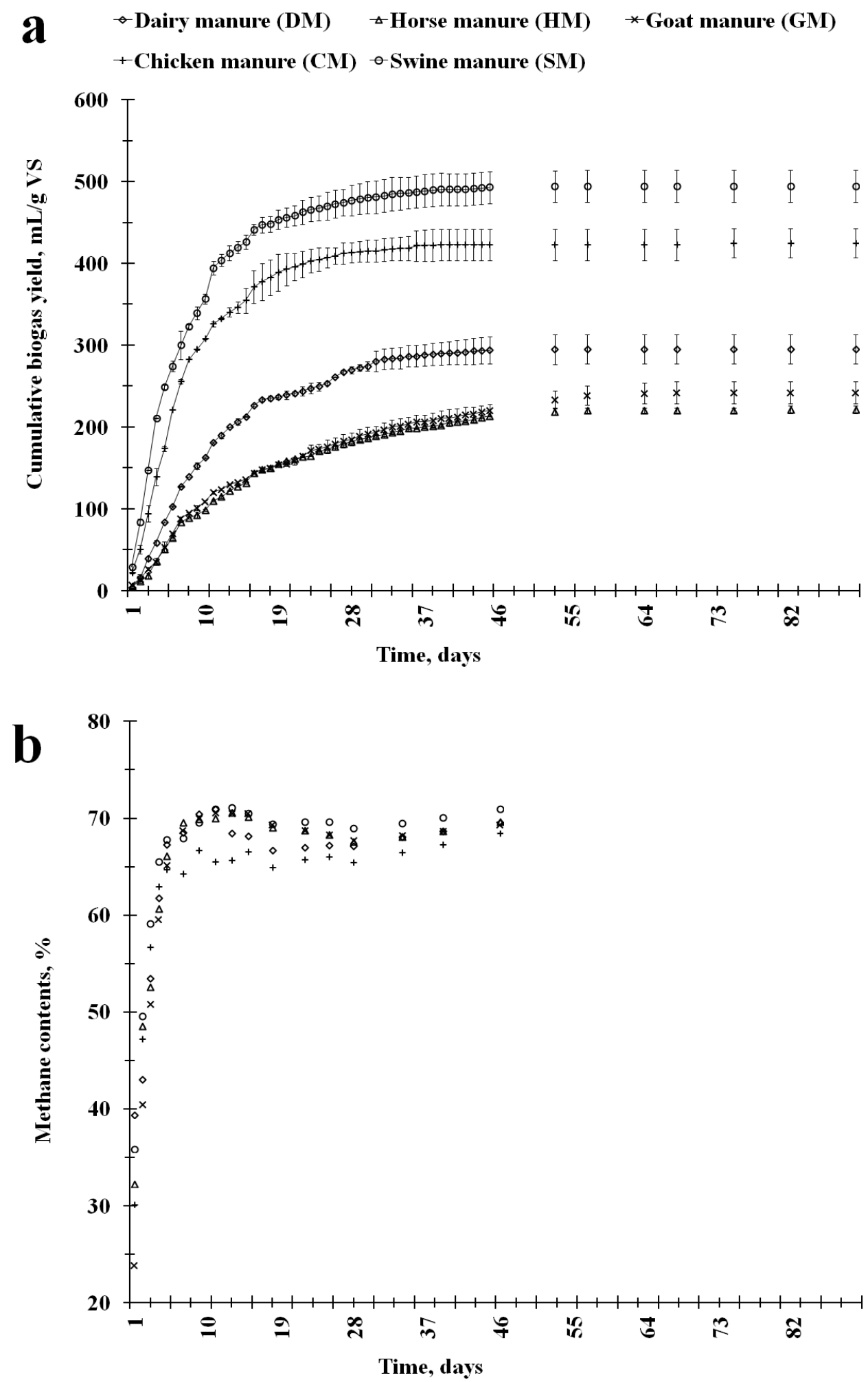

Fig.2 (a) Cumulative biogas yield; (b) methane contents for biogas produced from different manures. The values are means \pm standard deviations (vertical bars, $n=3$ rd deviations). 

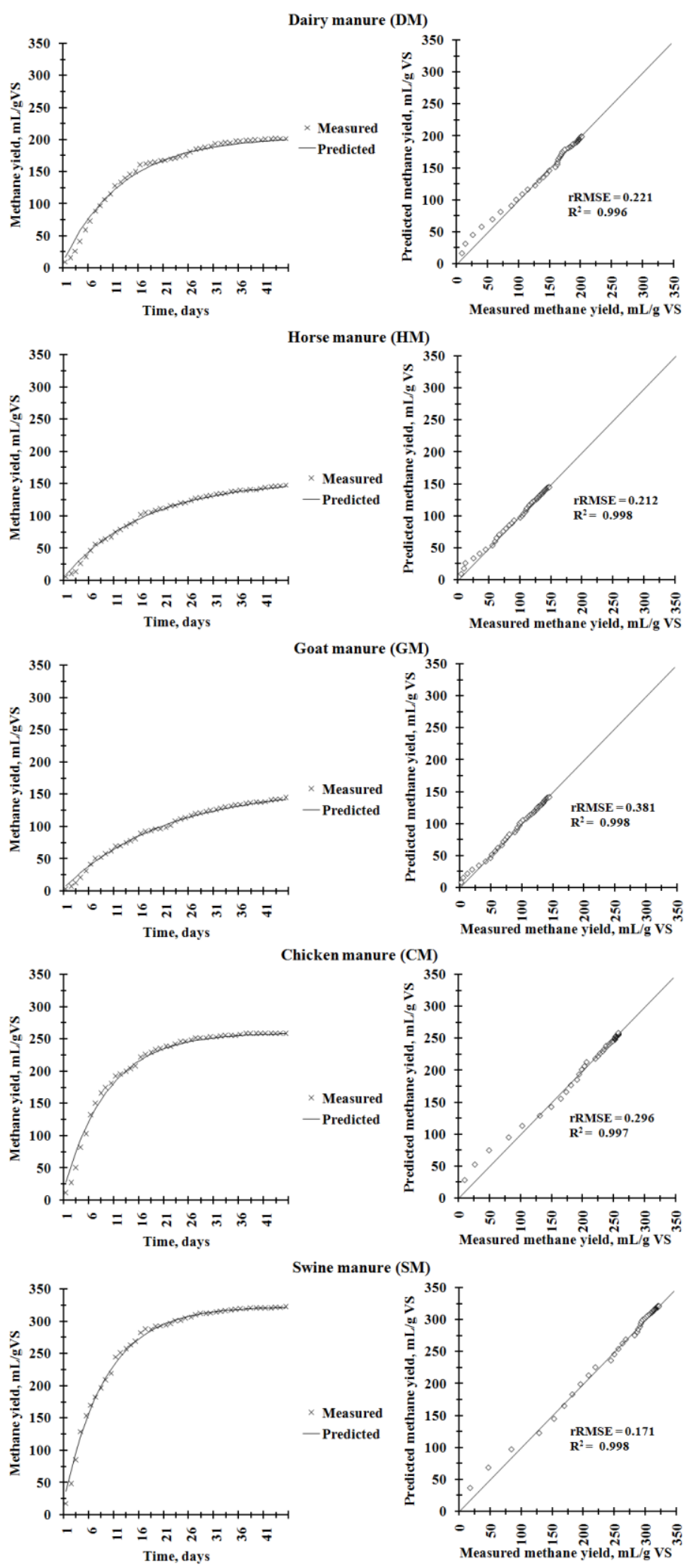

Swine manure (SM)

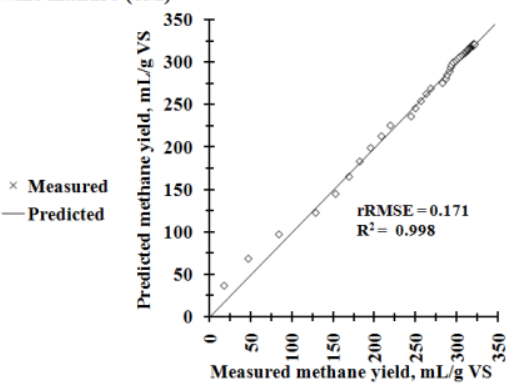

Fig.3 Measured methane yield plotted with methane yield predicted using first order kinetic model. 

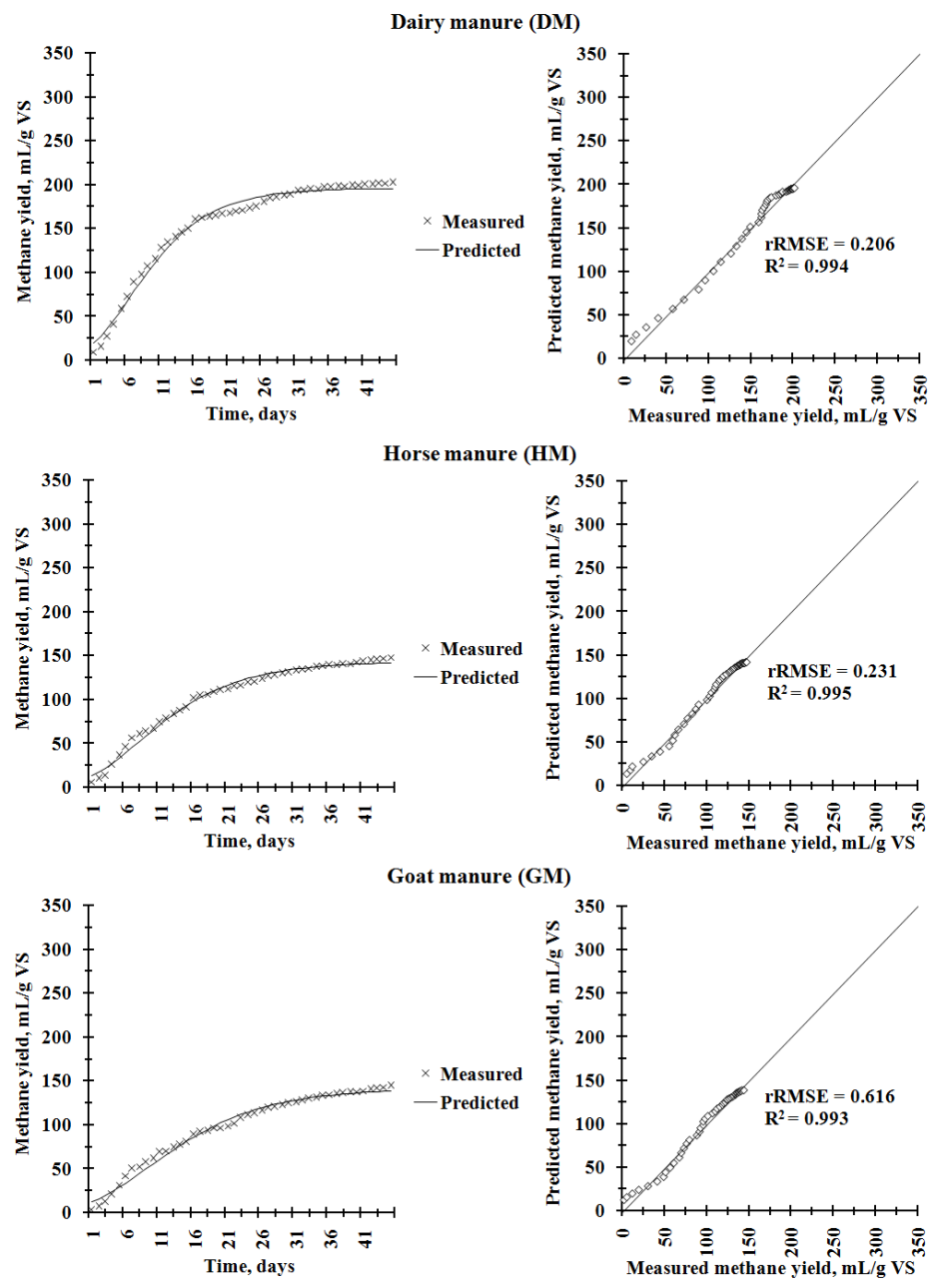

Goat manure (GM)
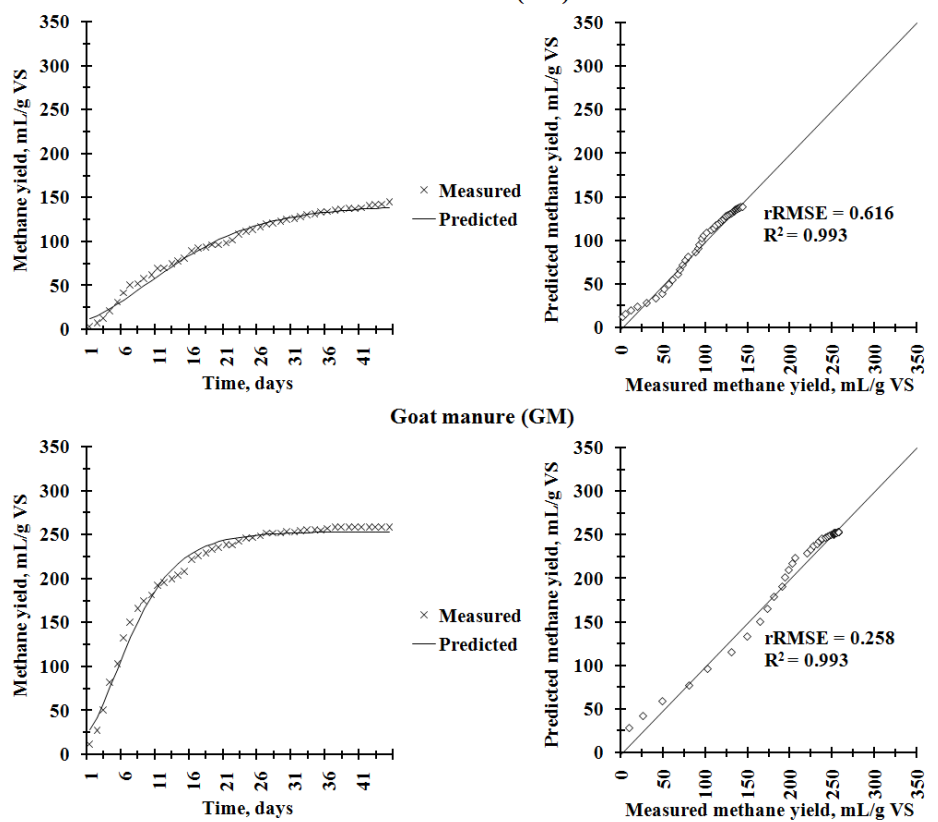

Goat manure (GM)
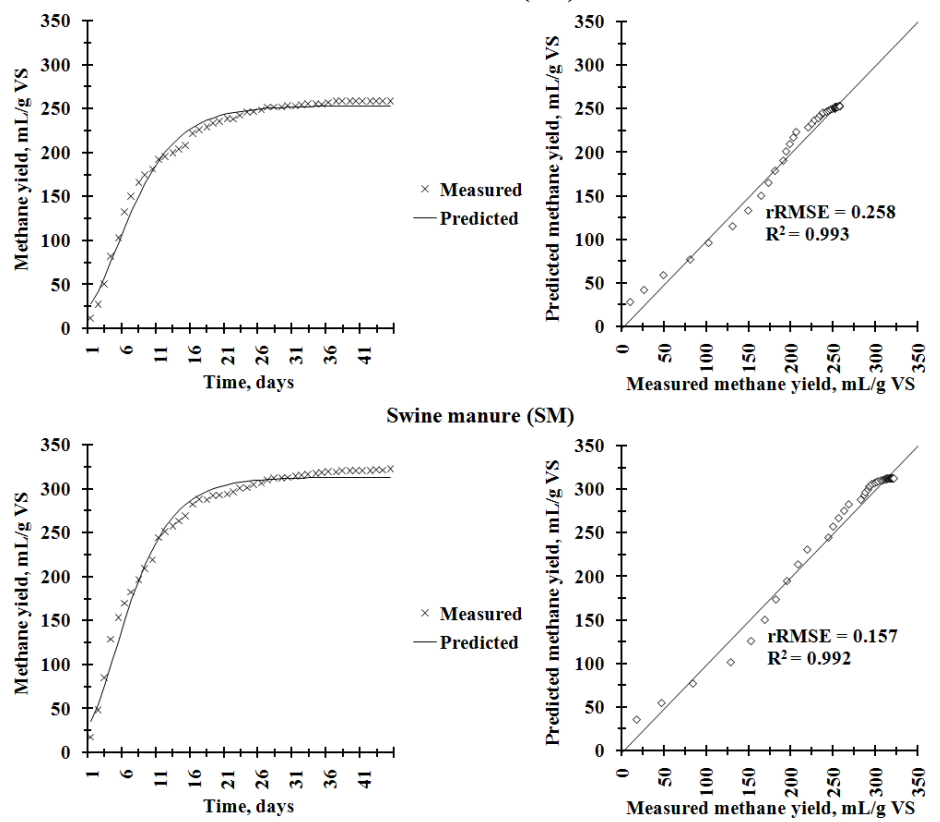

wine manure (SM)

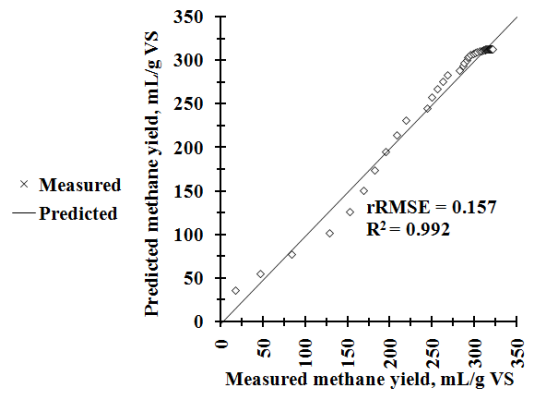

Fig.4 Measured methane yield plotted with methane yield predicted using modified Gompertz model. 

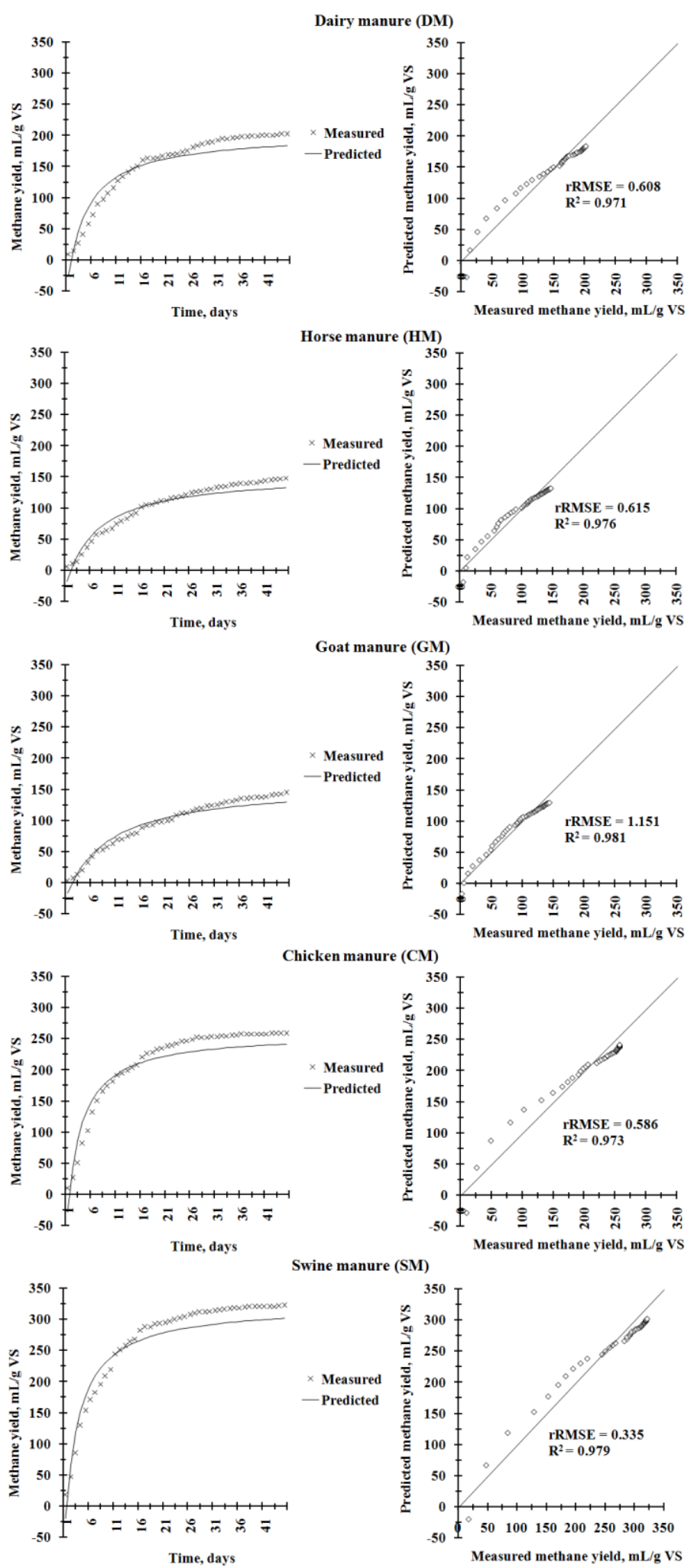

Fig. 5 Measured methane yield plotted with methane yield predicted using Chen and Hashimoto model. 
Table 1 Characteristics of five different manures and inoculum.

\begin{tabular}{|c|c|c|c|c|c|c|c|}
\hline \multirow[t]{2}{*}{ Feed } & \multirow[t]{2}{*}{ Units } & \multicolumn{6}{|l|}{ Manures } \\
\hline & & $\mathrm{DM}$ & $\mathrm{HM}$ & GM & $\mathrm{CM}$ & SM & Inoculum \\
\hline TS & $\%$ & $16.91(0.10)$ & $24.97(0.06)$ & $81.63(0.27)$ & $67.84(0.47)$ & $31.02(0.29)$ & $2.831(0.02)$ \\
\hline VS & $\%$ & $10.25(0.19)$ & $18.61(0.04)$ & $64.23(0.19)$ & $47.5(0.26)$ & $26.93(0.29)$ & $1.06(0.01)$ \\
\hline $\mathrm{pH}$ & & $8.16(0.03)$ & $8.24-8.26$ & $8.13(0.03)$ & $7.95(0.04)$ & $7.87(0.03)$ & $7.98(0.02)$ \\
\hline Crude protein $(\mathrm{CP})$ & $\% \mathrm{TS}$ & 8.59 & 12.14 & 14.70 & 27.00 & 26.80 & - \\
\hline Crude Fiber (CF) & $\% \mathrm{TS}$ & 25.00 & 38.50 & 36.77 & 15.59 & 20.35 & - \\
\hline Total Fat(TF) & $\% \mathrm{TS}$ & 2.56 & 3.47 & 3.33 & 1.01 & 9.40 & - \\
\hline Total carbohydrate (TC) & $\% \mathrm{TS}$ & 46.87 & 59.75 & 61.49 & 43.19 & 51.15 & - \\
\hline $\mathrm{ADF}$ & $\% \mathrm{TS}$ & 48.31 & 50.98 & 39.70 & 18.21 & 24.42 & - \\
\hline Ash & $\% \mathrm{TS}$ & 41.98 & 24.64 & 20.48 & 28.8 & 12.65 & - \\
\hline $\mathrm{C} / \mathrm{N}$ ratio & & $25: 1$ & $23: 1$ & $20: 1$ & $10: 1$ & $12: 1$ & - \\
\hline Lignin (LIG) & $\% \mathrm{TS}$ & 9.33 & 18.14 & 13.68 & 5.07 & 3.81 & - \\
\hline
\end{tabular}

DM: Dairy manure; HM: Horse manure; GM: Goat manure; CM: Chicken manure; SM: Swine manure

TAN: Total ammonical nitrogen; TN: Total nitrogen

Value in parenthesis represent standard deviation $(n=3)$ 
Table 2 Measured biogas and methane potential, TS and VS removal, and biogas production duration for different animal manures.

\begin{tabular}{lllllll}
\hline Parameters & Units & Manure & & & & \\
& & DM & HM & GM & CM & SM \\
\hline Biogas potential & $\mathrm{mL} / \mathrm{g}$ VS & $295(18)$ & $222(5)$ & $242(13)$ & $425(17)$ & $495(20)$ \\
Methane potential & $\mathrm{mL} / \mathrm{g}$ VS & $204(12)$ & $155(2)$ & $159(9)$ & $259(9)$ & $323(13)$ \\
Methane contents & $\%$ & $69.1(0.2)$ & $70.1(0.4)$ & $65.8(0.0)$ & $61.1(0.5)$ & $65.3(0.0)$ \\
TS removal & $\%$ & $50.0(6.2)$ & $46.9(5.5)$ & $38.7(7.3)$ & $69.0(4.0)$ & $74.3(1.6)$ \\
VS removal & $\%$ & $58.6(6.1)$ & $52.9(6.1)$ & $46.4(7.1)$ & $81.4(4.4)$ & $81.4(2.4)$ \\
Biogas removed (BR) & g/g VS added & $0.304(0.019)$ & $0.226(0.006)$ & $0.259(0.014)$ & $0.478(0.022)$ & $0.532(0.021)$ \\
$T_{80}$ & Days & $19(4)$ & $27(1)$ & $31(1)$ & $13(1)$ & $12(1)$ \\
$T_{90}$ & Days & $28(4)$ & $37(2)$ & $44(2)$ & $18(1)$ & $17(1)$ \\
\hline
\end{tabular}

DM: Dairy manure; HM: Horse manure; GM: Goat manure; CM: Chicken manure; SM: Swine manure

$\mathrm{T}_{80}$ : Duration for $80 \%$ of biogas production

$\mathrm{T}_{90}$ : Duration for $90 \%$ of biogas production

Value in parenthesis represent standard deviation $(n=3)$ 
Table 3 Summary of statistical analysis results.

\begin{tabular}{|c|c|c|c|c|}
\hline \multirow[t]{2}{*}{ Parameters } & \multirow[t]{2}{*}{ Units } & \multicolumn{2}{|l|}{ LSD } & \multirow[t]{2}{*}{ p-value } \\
\hline & & $\alpha=0.05$ & $\alpha=0.01$ & \\
\hline \multicolumn{5}{|c|}{ Digester performance } \\
\hline Biogas yield & $\mathrm{mL} / \mathrm{g} \mathrm{VS}$ & 35.00 & 51.00 & $4.02 \mathrm{E}-05$ \\
\hline Methane yield & $\mathrm{mL} / \mathrm{g} \mathrm{VS}$ & 22.00 & 31.00 & $4.65 \mathrm{E}-05$ \\
\hline Methane contents & $\%$ & 0.70 & 1.00 & $5.02 \mathrm{E}-06$ \\
\hline VS removal & $\%$ & 12 & 18 & 0.003615 \\
\hline TS removal & $\%$ & 12.00 & 17.00 & 0.004376 \\
\hline BR & $\mathrm{g} / \mathrm{g}$ VS removed & 0.040 & 0.057 & $3.67 \mathrm{E}-05$ \\
\hline $\mathrm{pH}$ & & 0.05 & 0.07 & 2.61E-06 \\
\hline TAN & $\mathrm{mg} / \mathrm{L}$ & 52.00 & 71.00 & 0.004822 \\
\hline TKN & $\mathrm{mg} / \mathrm{L}$ & 92.00 & 125.00 & 0.002529 \\
\hline $\mathrm{NO}_{2}^{-}-\mathrm{N}+\mathrm{NO}_{3}^{-}-\mathrm{N}$ & $\mathrm{mg} / \mathrm{L}$ & 16 & - & 0.020729 \\
\hline K & $\mathrm{mg} / \mathrm{L}$ & 45.00 & 61.00 & $5.92 \mathrm{E}-06$ \\
\hline $\mathrm{PO}_{4}^{-3}$ & $\mathrm{mg} / \mathrm{L}$ & 61.000 & 83.000 & $3.52 \mathrm{E}-05$ \\
\hline TVFA & $\mathrm{mg} / \mathrm{L}$ & 90 & 124 & $1.43 \mathrm{E}-08$ \\
\hline Alkalinity & $\mathrm{mg} / \mathrm{L}$ & 105 & 143 & $5.98 \mathrm{E}-09$ \\
\hline TVFA/alkalinity & & 0.023 & 0.031 & 4.18E-09 \\
\hline SCOD & $\mathrm{mg} / \mathrm{L}$ & 207 & 284 & $9.22 \mathrm{E}-06$ \\
\hline TCOD & $\mathrm{mg} / \mathrm{L}$ & 790 & 1080 & 5.83E-09 \\
\hline
\end{tabular}

LSD: Least significant difference

TAN: Total ammonical nitrogen; TN: Total nitrogen 
Table 4 Characteristics of influent and effluent for tests using different manures.

\begin{tabular}{|c|c|c|c|c|c|c|}
\hline \multirow[t]{2}{*}{ Chemical parameters } & & \multicolumn{5}{|l|}{ Manures } \\
\hline & & DM & HM & GM & $\mathrm{CM}$ & SM \\
\hline \multirow[t]{2}{*}{$\mathrm{pH}$} & Influent & $8.16(0.03)$ & $8.10(0.03)$ & $8.13(0.03)$ & $7.95(0.04)$ & $7.87(0.03)$ \\
\hline & Effluent & $7.90(0.01)$ & $7.91(0.04)$ & $7.91(0.02)$ & $7.96(0.01)$ & $7.95(0.02)$ \\
\hline \multirow[t]{2}{*}{ TVFA(mg/L) } & Influent & $707(68)$ & $546(4)$ & $567(7)$ & $732(5)$ & $828(4)$ \\
\hline & Effluent & $108(23)$ & $75(23)$ & $42(23)$ & $166(59)$ & 281(94) \\
\hline \multirow{2}{*}{$\mathrm{TA}(\mathrm{mg} / \mathrm{L})$} & Influent & $3580(42)$ & $3434(47)$ & $3460(42)$ & $3805(21)$ & $3500(14)$ \\
\hline & Effluent & $4065(64)$ & $4110(14)$ & $4180(113)$ & $4340(0)$ & $4460(42)$ \\
\hline \multirow[t]{2}{*}{ TVFA/alkalinity ratio } & Influent & $0.198(0.021)$ & $0.159(0.001)$ & $0.164(0.000)$ & $0.192(0.000)$ & $0.237(0.000)$ \\
\hline & Effluent & $0.026(0.006)$ & $0.018(0.006)$ & $0.010(0.005)$ & $0.038(0.014)$ & $0.063(0.022)$ \\
\hline \multirow{2}{*}{ TAN(mg/L) } & Influent & $520(28)$ & $470(28)$ & $500(14)$ & $560(14)$ & $510(14)$ \\
\hline & Effluent & $560(14)$ & $570(0)$ & $620(42)$ & $510(42)$ & $620(42)$ \\
\hline \multirow[t]{2}{*}{$\mathrm{TN}(\mathrm{mg} / \mathrm{L})$} & Influent & $1037(7)$ & $1026(9)$ & 1002(9) & $1185(9)$ & $1116(9)$ \\
\hline & Effluent & $975(85)$ & 891(17) & $960(21)$ & $1085(108)$ & $995(23)$ \\
\hline \multirow[t]{2}{*}{$\mathrm{TKN}(\mathrm{mg} / \mathrm{L})$} & Influent & $1005(8)$ & $984(8)$ & $957(8)$ & $1152(8)$ & 1092(8) \\
\hline & Effluent & $956(83)$ & $870(17)$ & $939(17)$ & $1070(104)$ & $978(25)$ \\
\hline \multirow[t]{2}{*}{$\mathrm{NO}_{2}^{-}-\mathrm{N}+\mathrm{NO}_{3}^{-}-\mathrm{N}(\mathrm{mg} / \mathrm{L})$} & Influent & $32(15)$ & $42(17)$ & $45(0)$ & $33(0)$ & $24(0)$ \\
\hline & Effluent & $19(2)$ & $21(0)$ & $21(4)$ & $15(4)$ & $16(2)$ \\
\hline \multirow[t]{2}{*}{$\mathrm{K}(\mathrm{mg} / \mathrm{L})$} & Influent & $620(11)$ & $600(28)$ & $680(21)$ & $680(28)$ & $600(14)$ \\
\hline & Effluent & $760(28)$ & $720(0)$ & $780(28)$ & $730(14)$ & $845(21)$ \\
\hline \multirow[t]{2}{*}{$\mathrm{PO}_{4}{ }^{3-}(\mathrm{mg} / \mathrm{L})$} & Influent & $441(2)$ & $426(2)$ & $509(2)$ & $564(2)$ & $463(18)$ \\
\hline & Effluent & $581(30)$ & $564(65)$ & $576(34)$ & $730(8)$ & $602(42)$ \\
\hline \multirow[t]{2}{*}{$\mathrm{TCOD}(\mathrm{mg} / \mathrm{L})$} & Influent & $13750(71)$ & $14950(71)$ & $14200(71)$ & $15500(141)$ & $14600(141)$ \\
\hline & Effluent & $9000(1131)$ & $9350(212)$ & $10250(71)$ & $8900(141)$ & $8600(141)$ \\
\hline \multirow[t]{2}{*}{$\mathrm{SCOD}(\mathrm{mg} / \mathrm{L})$} & Influent & $2400(71)$ & $2400(71)$ & $2100(141)$ & $2200(57)$ & $3250(71)$ \\
\hline & Effluent & $2150(71)$ & $2450(71)$ & $2150(212)$ & $2100(0)$ & $2050(71)$ \\
\hline
\end{tabular}

Values in parenthesis represent standard deviation $(\mathrm{n}=3)$

DM: Dairy manure; HM: Horse manure; GM: Goat manure; CM: Chicken manure; SM: Swine manure

TAN: Total ammonical nitrogen; TN: Total nitrogen 
Table 5 Regression of methane potential using explanatory variables.

\begin{tabular}{|c|c|c|c|c|c|c|c|}
\hline \multirow[t]{2}{*}{ Explanatory variables } & \multirow[t]{2}{*}{ Equation } & \multirow[t]{2}{*}{$\overline{\mathrm{R}^{2}}$} & \multirow[t]{2}{*}{ Adj. $R^{2}$} & \multirow[t]{2}{*}{ SE } & \multirow[t]{2}{*}{$\mathrm{p}$-value } & \multicolumn{2}{|c|}{$\begin{array}{c}\% \text { difference between } \\
\text { measured and predicted value }\end{array}$} \\
\hline & & & & & & Range & $\operatorname{Mean}(\mathrm{SD})$ \\
\hline \multicolumn{8}{|l|}{ Simple linear regression } \\
\hline $\mathrm{TC}$ & $\mathrm{G}_{\mathrm{o}}=516.5-5.65 \mathrm{TC}$ & 0.398 & 0.197 & 64 & 0.254 & $5.1-29.5$ & $16.0(10.6)$ \\
\hline $\mathrm{CP}$ & $\mathrm{G}_{\mathrm{o}}=98.5+6.82 \mathrm{CP}$ & 0.668 & 0.558 & 47 & 0.091 & $9.0-24.9$ & $17.3(6.7)$ \\
\hline $\mathrm{TF}$ & $\mathrm{G}_{\mathrm{o}}=168.2+13.14 \mathrm{TF}$ & 0.347 & 0.130 & 67 & 0.296 & $1.1-37.7$ & $22.3(16.0)$ \\
\hline LIG & $\mathrm{G}_{0}=330.3-11.01 \mathrm{LIG}$ & 0.851 & 0.802 & 32 & 0.026 & 5.8-15.9 & 11.4(3.7) \\
\hline $\mathrm{ADF}$ & $\mathrm{G}_{\mathrm{o}}=362.2-3.91 \mathrm{ADF}$ & 0.633 & 0.510 & 50 & 0.108 & $4.9-30.1$ & $15.9(9.2)$ \\
\hline \multicolumn{8}{|l|}{ Multiple linear regression } \\
\hline $\mathrm{TC}, \mathrm{CP}$ & $\mathrm{G}_{\mathrm{o}}=283.6-3.11 \mathrm{TC}+5.6 \mathrm{CP}$ & 0.768 & 0.535 & 49 & $0.216,0.452$ & $6.7-15.8$ & $11.2(4.0)$ \\
\hline TC, TF & $G_{0}=515.5-6.85 \mathrm{TC}+16.29 \mathrm{TF}$ & 0.913 & 0.826 & 30 & $0.068,0.075$ & 1.5-15.7 & 7.5(5.3) \\
\hline $\mathrm{CP}, \mathrm{TF}$ & $\mathrm{G}_{0}=86.8+5.80 \mathrm{CP}+7.54 \mathrm{TF}$ & 0.768 & 0.539 & 49 & $0.197,0.452$ & $3.1-23.9$ & $14.4(10.5)$ \\
\hline TC, LIG & $\mathrm{G}_{\mathrm{o}}=233.9+2.30 \mathrm{TC}-13.42 \mathrm{LIG}$ & 0.876 & 0.752 & 36 & $0.109,0.591$ & $2.2-20.4$ & $10.7(7.9)$ \\
\hline $\mathrm{CP}, \mathrm{LIG}$ & $\mathrm{G}_{\mathrm{o}}=260.9+2.43 \mathrm{CP}-8.41 \mathrm{LIG}$ & 0.889 & 0.778 & 34 & $0.185,0.496$ & $0.3-14.1$ & $8.8(5.2)$ \\
\hline TF, LIG & $\mathrm{G}_{\mathrm{o}}=288.9+7.29 \mathrm{TF}-9.75 \mathrm{LIG}$ & 0.947 & 0.894 & 23 & $0.041,0.197$ & $0.9-13.0$ & 7.3(5.0) \\
\hline $\mathrm{L}, \mathrm{ADF}$ & $\mathrm{G}_{\mathrm{o}}=338.3-10.01 \mathrm{~L}-0.49 \mathrm{ADF}$ & 0.854 & 0.709 & 39 & $0.223,0.835$ & 7.4-15.3 & $11.2(3.5)$ \\
\hline $\mathrm{TC}, \mathrm{ADF}$ & $\mathrm{G}_{\mathrm{o}}=465.3+2.48 \mathrm{TC}-3.16 \mathrm{ADF}$ & 0.686 & 0.372 & 57 & $0.618,0.308$ & $0.3-19.2$ & $11.4(8.6)$ \\
\hline $\mathrm{CP}, \mathrm{ADF}$ & $\mathrm{G}_{\mathrm{o}}=130.2+6.03 \mathrm{CP}-0.48 \mathrm{ADF}$ & 0.669 & 0.338 & 58 & $0.685,0.955$ & $9.6-25.4$ & $17.1(6.5)$ \\
\hline $\mathrm{TF}, \mathrm{ADF}$ & $\mathrm{G}_{\mathrm{o}}=306.8+9.96 \mathrm{TF}-3.47 \mathrm{ADF}$ & 0.824 & 0.648 & 42 & $0.278,0.145$ & $2.2-27.1$ & $11.4(11.2)$ \\
\hline $\mathrm{TC}, \mathrm{CP}, \mathrm{TF}$ & $\mathrm{G}_{\mathrm{o}}=387.0-5.17 \mathrm{TC}+3.09 \mathrm{CP}+12.53 \mathrm{TF}$ & 0.999 & 0.995 & 5 & $0.045,0.073,0.045$ & $0.1-2.3$ & $1.0(1.1)$ \\
\hline TC, CP, LIG & $\mathrm{G}_{\mathrm{o}}=216.9-1.37 \mathrm{TC}+1.95 \mathrm{CP}-10.37 \mathrm{LIG}$ & 0.896 & 0.586 & 46 & $0.833,0.735,0.465$ & $1.3-18.3$ & $9.3(6.6)$ \\
\hline $\mathrm{CP}, \mathrm{TF}, \mathrm{LIG}$ & $\mathrm{G}_{0}=242.6-1.75 \mathrm{CP}+6.66 \mathrm{TF}-8.0 \mathrm{LIG}$ & 0.966 & 0.864 & 26 & $0.539,0.373,0.251$ & $0.4-13.8$ & $5.2(5.8)$ \\
\hline $\mathrm{TC}, \mathrm{CP}, \mathrm{ADF}$ & $\mathrm{G}_{\mathrm{o}}=65.5-4.59 \mathrm{TC}+12.7 \mathrm{CP}+4.67 \mathrm{ADF}$ & 0.808 & 0.234 & 62 & $0.550,0.571,0.725$ & $2.7-17.9$ & 11.1(5.6) \\
\hline $\mathrm{TC}, \mathrm{TF}, \mathrm{ADF}$ & $\mathrm{G}_{\mathrm{o}}=485.6-4.80 \mathrm{TC}+13.65 \mathrm{TF}-1.85 \mathrm{ADF}$ & 0.999 & 0.994 & 5 & $0.057,0.042,0.081$ & $0.4-2.4$ & $1.1(1.0)$ \\
\hline $\mathrm{CP}, \mathrm{TF}, \mathrm{ADF}$ & $\mathrm{G}_{\mathrm{o}}=478.8-4.79 \mathrm{CP}+12.18 \mathrm{TF}-6.09 \mathrm{ADF}$ & 0.838 & 0.351 & 57 & $0.821,0.493,0.631$ & $1.9-30.1$ & $10.4(12.2)$ \\
\hline TC, LIG, ADF & $\mathrm{G}_{\mathrm{o}}=237.2+2.25 \mathrm{TC}-13.19 \mathrm{LIG}-0.09 \mathrm{ADF}$ & 0.876 & 0.505 & 50 & $0.747,0.432,0.981$ & $2.5-20.5$ & $10.7(7.9)$ \\
\hline CP, LIG, ADF & $G_{0}=-163.8+12.85 \mathrm{CP}-13.06 \mathrm{LIG}+7.85 \mathrm{ADF}$ & 0.999 & 0.999 & 1 & $0.015,0.009,0.017$ & $0.1-0.5$ & $0.3(0.2)$ \\
\hline TF, LIG, ADF & $\mathrm{G}_{\mathrm{o}}=300.9+7.56 \mathrm{TF}-8.04 \mathrm{LIG}-0.83 \mathrm{ADF}$ & 0.956 & 0.824 & 30 & $0.370,0.333,0.731$ & $0.5-15.1$ & $5.9(6.6)$ \\
\hline
\end{tabular}

TC: Total carbohydrate; CP: Crude protein, TF: Total fat, LIG: Lignin, ADF: Acid detergent fiber 
Table 6 Summary of results of kinetic study using three different models.

\begin{tabular}{|c|c|c|c|c|c|c|c|}
\hline \multicolumn{2}{|l|}{ Parameter } & Units & DM & HM & GM & $\mathrm{CM}$ & SM \\
\hline \multicolumn{8}{|c|}{ First order kinetic model } \\
\hline \multicolumn{2}{|c|}{$\begin{array}{l}\text { First order disintegration rate } \\
\text { constant }(\mathrm{k})\end{array}$} & $1 / \mathrm{d}$ & 0.084 & 0.0676 & 0.0493 & 0.1139 & 0.1196 \\
\hline \multirow{3}{*}{$\begin{array}{l}\text { Methane yield } \\
\text { (45 days) }\end{array}$} & Measured & $\mathrm{mL} / \mathrm{g} \mathrm{VS}$ & 201.9 & 148.2 & 144 & 257.9 & 321.9 \\
\hline & Predicted & $\mathrm{mL} / \mathrm{g} \mathrm{VS}$ & 199.3 & 145.3 & 141.8 & 257.9 & 321.2 \\
\hline & Difference & $\%$ & 1.3 & 2 & 2.5 & 0 & 0.2 \\
\hline \multicolumn{8}{|c|}{ Modified Gompertz model } \\
\hline \multicolumn{2}{|l|}{ Lag phase $(\lambda)$} & $\mathrm{d}$ & 0 & 0 & 0 & 0 & 0 \\
\hline \multicolumn{2}{|l|}{$\mathrm{R}_{\mathrm{m}}$} & $\mathrm{mL} / \mathrm{g}$ VS.d & 11.9 & 6.5 & 5.5 & 19.2 & 25.2 \\
\hline \multirow[t]{3}{*}{ Methane yield } & Measured & $\mathrm{mL} / \mathrm{g} \mathrm{VS}$ & 201.9 & 148.2 & 144 & 257.9 & 321.9 \\
\hline & Predicted & $\mathrm{mL} / \mathrm{g}$ VS & 195.4 & 141.4 & 138.4 & 252.8 & 312.7 \\
\hline & Difference & $\%$ & 3.2 & 4.6 & 3.9 & 2 & 2.9 \\
\hline \multicolumn{8}{|c|}{ Chen and Hashimoto model } \\
\hline \multirow{2}{*}{\multicolumn{2}{|c|}{$\begin{array}{l}\text { Chen and Hashimoto kinetic } \\
\text { constant }\left(\mathrm{K}_{\mathrm{ch}}\right) \\
\text { Specific growth rate }\left(\mu_{\mathrm{m}}\right)\end{array}$}} & & 3.1 & 4.2 & 5.1 & 2.5 & 2.7 \\
\hline & & $1 / \mathrm{d}$ & 0.637 & 0.564 & 0.511 & 0.752 & 0.846 \\
\hline \multirow[t]{3}{*}{ Methane yield } & Measured & $\mathrm{mL} / \mathrm{g} \mathrm{VS}$ & 201.9 & 148.2 & 144 & 257.9 & 321.9 \\
\hline & Predicted & $\mathrm{mL} / \mathrm{g}$ VS & 183.3 & 132.4 & 129.4 & 241.3 & 301.4 \\
\hline & Difference & $\%$ & 9.2 & 10.7 & 10.2 & 6.4 & 6.4 \\
\hline
\end{tabular}

DM: Dairy manure; HM: Horse manure; GM: Goat manure; CM: Chicken manure; SM: Swine manure 